\title{
WILLINGNESS TO BODY DONATION AMONG THE POPULATION OF CORDOBA IN ARGENTINA
}

\author{
Susana N. Biasutto', Lucía M. Navarro', Sofía G. Siemsen ${ }^{1}$, Florencia Turri', \\ Nicolás Longoni ${ }^{1}$, Atilio J. Bertocchi Valle ${ }^{2}$, Marcos A. Spinelli ${ }^{1}$, Oscar $P$. \\ David $^{3}$, Daniel Urrutia ${ }^{3}$, Diego M. Weigandt ${ }^{2}$, Federico N. De Oro ${ }^{1}$, Isaías E. \\ Molina Vargas ${ }^{2}$ \\ ${ }^{1}$ Chair of Normal Anatomy, Faculty of Medical Sciences, National University of Cordoba, \\ Cordoba, Argentina \\ ${ }^{2}$ Faculty of Medical Sciences, National University of Cordoba, Cordoba, Argentina \\ ${ }^{3}$ Chair of Anatomy, Faculty of Dentistry, National University of Cordoba, Cordoba, Argentina
}

\begin{abstract}
Corpses are an irreplaceable resource for teaching and research in Anatomy. Voluntary donation is the source of cadavers, but in the National University of Cordoba we are struggling with a critical shortage due to the lack of an organized donation program. The objective of this study was to know the attitude of general population of the city of Cordoba about this subject and the profile of potential donors to develop a program. A survey was randomly distributed among older than 18 years. The questionnaire included demographic, educational, laboral and religious aspects and specific ones related to the willingness to donate the own body and reasons to do it, knowledge about this possibility, interest in further information. Two thousand and thirty responses were obtained from a population so diverse that we considered it as representative of the city. Among the respondents, $80 \%$ should be willing to donate organs for transplantation and $41 \%$ the whole body; with $45 \%$ who said to know about donation and $54 \%$ interested in more information. Main motives to donate were related to support teaching, research and science; while the main reason not to donate was associated with insuficient information. The profile of potential donors was obtained from the analysis of all the variables and we compared with other studies demonstrating that not only cultural and religious aspects may determine the willingness to donate but also the level of public information and facilities to register as donors.
\end{abstract}

Key words: Body donation; National University of Cordoba; Teaching-learning of Anatomy; Whole body donors; Anatomy research

\section{RESUMEN}

Los cuerpos son un recurso irremplazable para la enseñanza e investigación en Anatomía. La donación voluntaria es la fuente de cadáveres, pero en la Universidad Nacional de Córdoba estamos luchando con una escasez crítica debido a la falta de un programa organizado de donación. El objetivo de este estudio fue conocer la actitud de la población general de la ciudad de Córdoba acerca del tema y el perfil de los potenciales donantes para desarrollar un programa. Se distribuyó una encuesta al azar entre mayores de 18 años. El cuestionario incluyó aspectos demográficos, educativos, laborales y religiosos, y otros específicos sobre la voluntad de donar el propio cuerpo y las razones para ello, el conocimiento sobre esta posibilidad y el interés en mayor información. Se obtuvieron 2030 respuestas de una población tan diversa que la consideramos como representativa de la ciudad. Entre los encuestados, el $80 \%$ donaría sus órganos para trasplante y $41 \%$ el cuerpo completo, con el $45 \%$ que dijo saber sobre la donación y el $54 \%$ interesado en obtener mayor información. Los principales motivos para donar se relacionaron con el apoyo a la enseñanza, la investigación y la ciencia; mientras que la principal razón para no donar estuvo asociada a la información insuficiente. El perfil de los potenciales donantes se obtuvo del análisis de las diferentes variables y comparamos con otros trabajos demostrando que no solo los aspectos culturales y religiosos pueden determinar la voluntad de donar sino también el nivel de información pública y la facilidad para registrarse como donante.

Palabras clave: Donación del cuerpo; Universidad Nacional de Córdoba; Enseñanza-aprendizaje de la Anatomía; Investigación anatómica; Donantes de cuerpo completo.

* Correspondence to: Prof. Susana N. Biasutto.
subiasutto@gmail.com

Received: 3 November, 2020. Revised: 25 November, 2020. Accepted: 27 November, 2020. 


\section{INTRODUCTION}

The study of Antomy is recognized as basic and essential for medical training since ancient times and the human body is its corner stone. Corpses are an invaluable resource for teaching and research in Anatomy and have demonstrated to be irreplaceable for graduate and postgraduate student's training (Biasutto et al, 2006; Azer and Eizenberg, 2007; Cahill and Ettarh, 2008; Sugand et al, 2010; Cornwall et al., 2012; Dereje, 2014; Narvaez-Hernandez and Murillo-Rabago, 2014; Arráez-Aybar et al, 2014).

Cadaver donation provides $100 \%$ of the total corpses used for university teaching in Anatomy in Australia, Austria, Canada, Chile, Czech Republic, Denmark, France, German, Ireland, Japan, Malta, Netherlands, New Zealand, Poland, South Korea, Spain, Sri Lanka, Sweden, Switzerland, Thailand and United Kingdom, and most of the bodies in China, Portugal, South Africa, Taiwan, United States and Uruguay among the participating countries in the study of Habicht et al. (2018). In Netherlands, $0.1 \%$ of the total population are registered as donors (Bolt et al., 2010). But in many countries, the access to human remains is still problematic, with educational institutions struggling to get enough corpses for teaching and research (Cornwall et al., 2012).

Most of the articles based on body donation surveyed the attitude of students under different circumstances (Cahill and Ettarh, 2008; Asl et al., 2010; Anyanwu et al, 2014; Saha et al., 2015; Quiroga-Garza et al., 2017; Ciliberti et al., 2018; Biasutto et al., 2018a, 2019a, 2019b) or Anatomy professors and researchers (Arraez-Aybar et al., 2010; Anyanwu and Obikili, 2012; Emue et al., 2012; Quiroga-Garza et al., 2017); but only a relatively few are related to the feelings and willingness of general population about this topic (Boulware et al, 2004; Bolt et al., 2010; Rokade and Gaikawad, 2012; Halou et al, 2013; Asad et al, 2014; Larner et al, 2015; Techataweewan et al., 2018; Gürses et al, 2019; Volanek and Rissi, 2019; Jiang et al.,2020).

The National University of Cordoba, despite being one of the oldest universities in the american continent and strongly linked to European universities, never developed a structured whole body donation program. Currently we are only receiving donated bodies, but the lack of organized actions and the ingnorance of the population on the subject have conducted our Department to a critical shortage, with risk for Anatomy teaching-learning and research. Many years ago we began to work on the topic, but it was not easy to manage institutional support. In 2018 a two years research project was approved by the Science and Technology Secretary to investigate the attitude of different groups towards body donation, including general population at the city of Cordoba, with the aim of proposing a donation program (Biasutto et al., 2019a, 2019b, 2019c, 2020).

Then the objective of this study was focused on the general population, considered as potential donors for our university.

\section{MATERIAL AND METHOD}

This is a qualitative and relational cross-sectional study, based on anonymous surveys with multiple choice and semi-structured answers on random samples.

Two thousand and thirty surveys were voluntarily completed by people living in the city of Cordoba and surrounding towns (Great Cordoba), excluding medical and dentist students and professionals, who were involved in other studies of the same project (Biasutto et al., 2018a, 2019a, 2019b, 2019c, 2020). Questionnaires were randomly distributed in public places to individuals older than 18 years, trying to include a wide variety of ages and different social conditions. Survey was anonymous and participants were informed about the objectives to obtain consent for publication.

The survey included age, gender, nationality and province of origin, education level, religion, profession or work activity, neighbourhood, willingness to donate his/her organs for transplantation, knowledge about whole body donation, interest in learning about body donation, willingness to donate the own body and reasons for that.

Results were reported in percentages and differences were considered significant if $p<0.01$. Chi square test was used for the analysis of the results to evaluate the association of qualitative variables.

The statistical software used was INFOSTAT.

This study was carried on with the approval and support of the Science and Technology Secretary of the National University of Cordoba. Proyecto Formar 2018-19 - 33820180100313CB01

\section{RESULTS}

On the 2030 participants, 1040 (51\%) were women and $990(49 \%)$ men, with ages from 18 to 92 (mean age: $38.72 \pm 16.34$ ). Nine persons did not include their age. For better interpretation we 
considered four age groups: a) 18-30 years (mean age: $23.55 \pm 3,58$ ) 829 cases; b) 31-45 years $(37.87 \pm 4.42) 550$ cases; c) $46-60$ years $(52.43 \pm 4.36) \quad 390$ cases; d) over 60 years $(69,28 \pm 6.57) 252$ cases.

Ninety seven per cent (1967) were argentine and the $3 \%(63)$ of foreigners were from Peru (19), Venezuela (11), Paraguay (6), Bolivia (4), Colombia (3), Chile (2), United States (2), Brazil (1), Haiti (1), Italy (1) and 13 did not specified the country. Argentines from the province of Cordoba were $82 \%(1612)$ and the remaining belonged from all the provinces with prevalence of $\mathrm{La}$ Pampa, Buenos Aires, Santa Fe, Salta and Jujuy. The options for educational level included: A) university, with $693(34 \%)$; B) superior (nonuniversitary), 328 (16\%); C) high school, 744 (37\%); D) primary school, 245 (12\%); E) none, 13 (0.64\%) and F) did not answer, 7 (0.34\%). These options did not distinguish between complete or incomplete level.

While considering the religion, 1200 (59\%) were Catholics, $146 \quad(7 \%)$ were non-Catholic Christians, 15 were Jewish, 3 were Muslims, 13 belonged to other religions with minor representation in the country, $630(31 \%)$ did not professed any religion and 33 did not answer.

One hundred and fifty six different professions or work activities were informed, even if some of them were joined under a common nomination (for example: general services). To facilitate the analysis, we grouped these activities in the following way: I) Health professionals (excluding physicians and dentists) 96 (5\%); II) Non-health professionals $129(6 \%)$; III) Technicians $49(2 \%)$; IV) Officers $181(9 \%)$; V) Construction workers 274 (13\%); VI) Customer service staff 323 (16\%);
VII) Housewives 97 (5\%); VIII) Educators 110 (5\%); IX) Students (except medical and dentistry students) 362 (18\%); X) Retired 163 (8\%); XI) Unemployed $63(3 \%)$; and XII) Others $183(9 \%)$.

The city of Cordoba has 536 neighbourhoods. Of the total surveyed people, 1872 lived in 312 different neighbourhoods of different financial levels, 147 did not answer this item and 11 were illegible.

Of the whole group, $80 \%$ (1613) should be willing to donate their organs for transplantation; $45 \%$ (910) said to know about body donation for teaching and research; 54\% (1087) would be interested in obtaining more information about the donation of bodies, and $40.64 \%$ (825) were willing to donate their own bodies.

The information provided above shows the characteristics of the surveyed people. In the following paragraphs we shall associate those different aspects included in the questionnaire with the willingness to donate the own body.

Women demonstrated more positive attitude to donation than men. Four hundred and fifty two women would be willing to donate, representing $55 \%$ of the total potential donors and $43 \%$ of total women; while 373 men could donate their bodies, $38 \%$ of men $(p=0.0080)$.

The table 1 shows each age group attitude towards donation with statistically significant differences $(p=<0.0001)$, evidencing better disposition in the extreme age groups.

Argentines were more willing to donate than foreigners $(41 \%-24 \%, p=0.0059)$ and those residents from other provinces were more willing than natives from Cordoba $(49 \%-39 \%$, $\mathrm{p}=0.0016$ ).

\begin{tabular}{|l|l|c|c|}
\hline Age groups & Will to donate & $\mathbf{N}$ & $\mathbf{\%}$ \\
\hline $\mathbf{1 8 - 3 0}$ & YES & 397 & $\mathbf{4 7 , 8 9 \%}$ \\
& NO & 424 & $51,15 \%$ \\
& Empty & 8 & $0,97 \%$ \\
\hline $\mathbf{3 1 - 4 5}$ & YES & 187 & $34 \%$ \\
& NO & 349 & $63,45 \%$ \\
& Empty & 14 & $2,55 \%$ \\
\hline $\mathbf{4 6 - 6 0}$ & YES & 137 & $35,13 \%$ \\
& NO & 249 & $63,85 \%$ \\
& Empty & 4 & $1,03 \%$ \\
\hline Más 60 & YES & 101 & $\mathbf{4 0 , 0 8} \%$ \\
& NO & 148 & $58,73 \%$ \\
& Empty & 3 & $1,19 \%$ \\
\hline
\end{tabular}

Table 1- Relation between age groups and willingness to donate of each one. 


\begin{tabular}{|l|c|c|c|}
\hline Education level & Donors & \%/total & \%/category \\
\hline None & 4 & $0.48 \%$ & $30.77 \%$ \\
Primary school & 70 & $8.48 \%$ & $28.57 \%$ \\
High school & 263 & $31.88 \%$ & $35.35 \%$ \\
Superior & 153 & $18.55 \%$ & $46.65 \%$ \\
University & 334 & $40.48 \%$ & $48.20 \%$ \\
Empty & 1 & $0.12 \%$ & $16.67 \%$ \\
\hline
\end{tabular}

Table 2- Relation between the eductional level of the participants and willingness to donate their own bodies.

The association with educational level showed that the willingness to donate is directly related to higher education, with significant differences $(p=<0.0001)$. Table 2 shows the details.

Catholics appeared as main donors (53\%) because it is the biggest religious cult in
Argentina and most of the respondents profess it; but if we consider each group independently (Table 3) we realize that the highest percentage of donors were those who do not profess any religion ( $52 \%$ vs. $37 \%$ of Catholics, $p=<0.0001)$.

\begin{tabular}{|l|c|c|c|}
\hline Religion & Donors & $\mathbf{\% / t o t a l}$ & $\mathbf{\% / c a t e g o r y}$ \\
\hline Catholics & 439 & $\mathbf{5 3 , 2 1 \%}$ & $36,58 \%$ \\
\hline Non-catholic Christians & 52 & $6,30 \%$ & $35,62 \%$ \\
\hline Jewish & 1 & $0,12 \%$ & $6,67 \%$ \\
\hline Muslims & 0 & $0 \%$ & $0 \%$ \\
\hline Other & 4 & $0,48 \%$ & $30,77 \%$ \\
\hline None & 322 & $\mathbf{3 9 , 0 3 \%}$ & $\mathbf{5 1 , 9 4 \%}$ \\
\hline Empty & 7 & $0,85 \%$ & $21,21 \%$ \\
\hline
\end{tabular}

Table 3- Relation between religious practice and willingness to donate

\begin{tabular}{|l|c|c|c|}
\hline Work Acttivity & Donors & \%/total & \%/category \\
\hline Officers & 71 & $8,61 \%$ & $39,23 \%$ \\
\hline Health professionals & 35 & $4,24 \%$ & $36,46 \%$ \\
\hline Non-health profes. & 58 & $7,03 \%$ & $\mathbf{4 4 , 9 6 \%}$ \\
\hline Technicians & 20 & $2,42 \%$ & $\mathbf{4 0 , 8 2 \%}$ \\
\hline Construction workers & 81 & $9,82 \%$ & $29,56 \%$ \\
\hline Students & 205 & $\mathbf{2 4 , 8 5 \%}$ & $\mathbf{5 6 , 6 3 \%}$ \\
\hline Educators & 46 & $5,58 \%$ & $\mathbf{4 1 , 8 2 \%}$ \\
\hline Customer service & 119 & $\mathbf{1 4 , 4 2 \%}$ & 36,84 \\
\hline Unemployed & 20 & $\mathbf{2 , 4 2 \%}$ & 31,75 \\
\hline Housewives & 32 & $3,88 \%$ & 32,99 \\
\hline Retired & 56 & $6,79 \%$ & $34,36 \%$ \\
\hline Others & 82 & $4,04 \%$ & $44,81 \%$ \\
\hline
\end{tabular}

Table 4- Relation between work activity and willingness to donate. 
Association between working activity and donation is provided by Table 4 . Students $(57 \%)$, non-health professionals $(45 \%)$, educators $(42 \%)$ and technicians $(41 \%)$ were the activities with highest percentage of potential donors. However it was notorious that none group of activities showed percentages lower than $30 \%$. In spite of that, differences among working activities was significantly different $(p=<0.0001)$.

Forty nine per cent (790) of those who should donate organs for transplantation would also donate their whole bodies for teaching and research.

Sixty three per cent (738) of those who would not donate were unaware of the possibility of donating before the survey and $35 \%$ (412) were interested in obtaining information.

\begin{tabular}{|c|c|c|}
\hline Motives to donate & N & $\%$ \\
\hline Teaching-learning & 119 & 17.66 \\
\hline To help & 104 & 15.43 \\
\hline For research & 100 & 14.84 \\
\hline Contribution to science & 83 & 12.31 \\
\hline It does not serve me & 39 & 5.79 \\
\hline Teaching and research & 30 & 4.45 \\
\hline It is important & 15 & 2.23 \\
\hline It is a need & 13 & 1.93 \\
\hline To be useful & 8 & 1.19 \\
\hline A good option & 5 & 0.74 \\
\hline I will not need it & 5 & 0.74 \\
\hline Good deed & 4 & 0.59 \\
\hline Never thought before & 4 & 0.59 \\
\hline Depends on the family & 3 & 0.45 \\
\hline Lack of information & 3 & 0.45 \\
\hline Preference for cremation & 3 & 0.45 \\
\hline To give life & 3 & 0.45 \\
\hline Another option & 2 & 0.30 \\
\hline Better use & 2 & 0.30 \\
\hline Curiosity & 2 & 0.30 \\
\hline Familiar decision & 2 & 0.30 \\
\hline I do not know yet & 2 & 0.30 \\
\hline I do not like & 2 & 0.30 \\
\hline Believes & 1 & 0.15 \\
\hline Does not matter & 1 & 0.15 \\
\hline For knowledge & 1 & 0.15 \\
\hline For life & 1 & 0.15 \\
\hline I do not like burial & 1 & 0.15 \\
\hline
\end{tabular}

\begin{tabular}{|c|c|c|}
\hline I do not want to rot & 1 & 0.15 \\
\hline I like & 1 & 0.15 \\
\hline I will be dead & 1 & 0.15 \\
\hline It interests me & 1 & 0.15 \\
\hline It is mine & 1 & 0.15 \\
\hline It is not mine & 1 & 0.15 \\
\hline Looks fine & 1 & 0.15 \\
\hline Love to Medicine & 1 & 0.15 \\
\hline Matter without life & 1 & 0.15 \\
\hline Nothing is missed & 1 & 0.15 \\
\hline Relatives in Medicine & 1 & 0.15 \\
\hline Social contribution & 1 & 0.15 \\
\hline Thanks to science & 1 & 0.15 \\
\hline To improve life & 1 & 0.15 \\
\hline To improve Medicine & 1 & 0.15 \\
\hline To make it better & 1 & 0.15 \\
\hline To save lives & 1 & 0.15 \\
\hline Empty & $\mathbf{9 9}$ & $\mathbf{1 4 . 6 9}$ \\
\hline
\end{tabular}

Table 5- Reasons expressed by respondents for donating their bodies to teaching and research. Absolute $(\mathrm{N})$ and proportional values within the group (\%).

Reasons to donate or not donate were freely expressed by the respondents (not multiple choice answers). In the group of those who would donate, altruism prevailed (Table 5). Those who wanted to support teaching, research and science represented $49.26 \%$, and those who considered donation important, useful and needed were $5.35 \%$ of the potential donors. Instead both lists were long (Table 5 and 6), that including the reasons of individuals negative to donation was of a great variety of expressions, not always clear (Table 6).

\begin{tabular}{|c|c|c|}
\hline Motives not to donate & N & $\%$ \\
\hline Lack of information & 125 & 10.65 \\
\hline Just no & 89 & 7.58 \\
\hline For the family & 70 & 5.96 \\
\hline It doesn't like me & 69 & 5.88 \\
\hline Not interested & 67 & 5.71 \\
\hline Priority for transplantati.. & 62 & 5.28 \\
\hline Preference for cremation & 46 & 3.92 \\
\hline Religious reasons & 38 & 3.24 \\
\hline Burial preference & 35 & 2.98 \\
\hline Didn't think yet & 34 & 2.90 \\
\hline Modesty & 33 & 2.81 \\
\hline Don't know yet & 20 & 1.70 \\
\hline Distrust & 17 & 1.45 \\
\hline & &
\end{tabular}




\begin{tabular}{|c|c|c|}
\hline Familiar decision & 12 & 1.02 \\
\hline To rest in peace & 12 & 1.02 \\
\hline Disrespect for the dead & 11 & 0.94 \\
\hline Personal reasons & 10 & 0.85 \\
\hline Believes & 9 & 0.77 \\
\hline For disagreement & 9 & 0.77 \\
\hline I don't want & 9 & 0.77 \\
\hline Bad impression & 8 & 0.68 \\
\hline Fear & 8 & 0.68 \\
\hline It is my body & 7 & 0.60 \\
\hline Personal decision & 6 & 0.51 \\
\hline For the exhibition & 5 & 0.43 \\
\hline Other source & 5 & 0.43 \\
\hline Save lives & 4 & 0.34 \\
\hline Unpleasant & 4 & 0.34 \\
\hline I want a veil & 3 & 0.26 \\
\hline Inapropriate & 3 & 0.26 \\
\hline Useless & 3 & 0.26 \\
\hline Avoid experiments & 2 & 0.17 \\
\hline Business & 2 & 0.17 \\
\hline By manipulation & 2 & 0.17 \\
\hline Donate another & 2 & 0.17 \\
\hline They fight for my life & 2 & 0.17 \\
\hline It is morbid & 2 & 0.17 \\
\hline It make me sick & 2 & 0.17 \\
\hline Keep intact & 2 & 0.17 \\
\hline Look for other option & 2 & 0.17 \\
\hline Moral issue & 2 & 0.17 \\
\hline Never & 2 & 0.17 \\
\hline Nothing & 2 & 0.17 \\
\hline Unnecessary & 2 & 0.17 \\
\hline Use unclaimed bodies & 2 & 0.17 \\
\hline A lie & 1 & 0.09 \\
\hline All negative & 1 & 0.09 \\
\hline Another option & 1 & 0.09 \\
\hline Attached to my body & 1 & 0.09 \\
\hline Avoid body injuries & 1 & 0.09 \\
\hline Because of misuse & 1 & 0.09 \\
\hline Because of reification & 1 & 0.09 \\
\hline Because of research & 1 & 0.09 \\
\hline By principles & 1 & 0.09 \\
\hline Christian burial & 1 & 0.09 \\
\hline Contribute to science & 1 & 0.09 \\
\hline Convictions & 1 & 0.09 \\
\hline Cultural issue & 1 & 0.09 \\
\hline Depends on who receives & 1 & 0.09 \\
\hline To donate as much as possible & 1 & 0.09 \\
\hline Donation only for my family & 1 & 0.09 \\
\hline Doubts & 1 & 0.09 \\
\hline Emotional attachment & 1 & 0.09 \\
\hline Ethical-moral reasons & 1 & 0.09 \\
\hline Feeling of disconfort & 1 & 0.09 \\
\hline Feeling of invasion & 1 & 0.09 \\
\hline For caution & 1 & 0.09 \\
\hline For my age & 1 & 0.09 \\
\hline For respect & 1 & 0.09 \\
\hline Hesitation & 1 & 0.09 \\
\hline I donated & 1 & 0.09 \\
\hline I won't need it & 1 & 0.09 \\
\hline Incomprehensible & 1 & 0.09 \\
\hline
\end{tabular}

\begin{tabular}{|c|c|c|}
\hline It is my temple & 1 & 0.09 \\
\hline It is wrong & 1 & 0.09 \\
\hline Lack of control & 1 & 0.09 \\
\hline Lack of security & 1 & 0.09 \\
\hline Misunderstanding & 1 & 0.09 \\
\hline Moral objection & 1 & 0.09 \\
\hline No motives & 1 & 0.09 \\
\hline Not an animal & 1 & 0.09 \\
\hline Not applicable & 1 & 0.09 \\
\hline Not good & 1 & 0.09 \\
\hline Not important & 1 & 0.09 \\
\hline Not my will & 1 & 0.09 \\
\hline Not now & 1 & 0.09 \\
\hline Not suitable & 1 & 0.09 \\
\hline Not sure & 1 & 0.09 \\
\hline Private motives & 1 & 0.09 \\
\hline Reencarnación & 1 & 0.09 \\
\hline Sacred body & 1 & 0.09 \\
\hline Seems odd & 1 & 0.09 \\
\hline Sin & 1 & 0.09 \\
\hline Teaching and research & 1 & 0.09 \\
\hline Tear the body to pieces & 1 & 0.09 \\
\hline Terrorism & 1 & 0.09 \\
\hline To be tree compost & 1 & 0.09 \\
\hline To be useful & 1 & 0.09 \\
\hline To give life & 1 & 0.09 \\
\hline To preserve the whole body & 1 & 0.09 \\
\hline Traffic & 1 & 0.09 \\
\hline Unacceptable & 1 & 0.09 \\
\hline Unethical & 1 & 0.09 \\
\hline Empty & 255 & 21.72 \\
\hline & & \\
\hline & & \\
\hline & 1 & 1 \\
\hline
\end{tabular}

Table 6- Reasons expressed by respondents for not donating their bodies to teaching and research. Absolute $(\mathrm{N})$ and proportional values within the group (\%).

The lack of information (10.65\%) was the most frequent and reasonable motive to oppose; followed by "just no" (7.58\%), "for my family" (5.96\%), "doesn't like" (5.88\%), "not interested" $(5.71 \%)$ evidencing a not well founded opinion, and "priority for transplantation" $(5.28 \%)$ showing the lack of knowledge of this subject. In both groups (Table 5 and 6) we could observe a high percentage of non-respondents.

We consider this information very valuable for the design of a body procurement and donation program.

\section{DISCUSSION}

Only few articles were found evaluating the attitude of local people towards body donation. In those countries with body donation law and/or programs for decades, it should not be necessary, except they evidenced a reduction (Boulware et al., 2004). 
In South America all the countries have difficulties with the provision of bodies, except Uruguay with a law involving whole body donation and a program since a century (Biasutto et al., 2018b)

The present study included a sample with sufficient breadth and diversity to be representative of Cordoba population.

We consider $41 \%$ of general population with a positive attitude to donation as very auspicious for a donation program, but it is significantly lower than the $49 \%(p=0.0022)$ reported for Boulware et al. (2004) in Baltimore-USA. However it is important to consider that Boulware conducted the study in a society with a well organized program but a low donation rate, instead of our lack of program and public information. On the other side, of 1500 Greek survey participants (Halou et al., 2013) only 5\% were willing to donate their bodies $(p=<0.0001), \quad 19 \%$ $(p=<0.0001)$ among 380 Indians of Maharashtra aware of body donation (Rokade and Gaikawad, 2012) and $25 \%$ of Brazilians in Campinas on 100 surveyed (Volanek and Rissi, 2019).

Women were more likely to donate than men, in contrast with studies performed in medical students and professionals with better dispossal of men ( $p=0.0005$ and $p=0.0012$ respectively) (Biasutto et al., 2019b, c). This information also contrasted with the study of Gürses et al. (2019) on Turkish donors, with $2 / 3$ of men among the respondents, on Indians (Rokade and Gaikawad, 2012) and Jiang et al. (2020) on Chinese with $67 \%$ of male donors. But studies carried out in the University of Nijmegen (Netherlands) showed the same percentages than our study (women/men, 51\%-49\%). (Bolt et al., 2010); Techataweewan et al. (2018) in Thailand and Cornwall et al. (2012) study on New Zealand, South Africa and Ireland donors also evidenced similarity compared with our results $(p=0.6542$, $\mathrm{p}=0.0722$ and $\mathrm{p}=0.8125$ respectively). Among Greek population (Halou et al., 2013) women were also more willing to donate, even more than our study $(p=<0.0001)$, on a very small group of potential donors.

Younger than thirty was the age group with higher percentage of potential donors, probably due to the concept that death is something distant for them, an unconscious certainty that it will never happen to one. However, the second most frequent group were those over 60 years, with opposite life conditions. For Boulware et al. (2004) increasing age was associated with 50$60 \%$ less odds of willingness to become a whole body donor, similar to the decrease reported by Rokade and Gaikawad (2012).

Gürses et al. (2019) identified nearly $50 \%$ of donors with tertiary educational level, in a great similarity with our study $(p=0.6087)$. Many authors (Boulware et al., 2004; Rokade and Gaikawad, 2012; Halou et al., 2012) reported greater education associated with increasing will to donate. In contrast, Bolt et al. (2010) found that $59 \%$ of Dutch donors had secondary education and $22 \%$ had tertiary education $(p=<0.0001)$, and Cornwall et al (2012) reported $63-72 \%$ who had completed secondary school and $26-43 \%$ had attended tertiary education.

Non-professing people showed the highest percentage of willingness to donate but, considering the total number, Catholics showed the highest rate of positive attitude, similar to Cornwall et al. (2012) about Christians, and differentiating from Gürses et al (2019) who informed a higher percentage of "irreligious" $(p=<0.0001)$ and Bolt et al. (2010) reporting only $21 \%$ as members of a church or religious community $(p=<0.0001)$. Boulware et al. (2004) associated strong religious faith with lower percentages.

For Cornwall et al. (2012) clerical and trade occupations were more involved in donation than professionals and managers, evidencing a difference with our results. Motivations described for body donation among Dutch (Bolt et al., 2010), South Africans, New Zealanders and Irish (Cornwall et al., 2012), Thai (Techataweewan et al., 2018) and Brazilians (Volanek and Rissi, 2019) were the same than ours, evidencing altruism and solidarity as prevalent feelings. However, in those other articles appeared the dislike of funerals and concern about costs not present in our study; in any case Cordoba survey respondents considered the bodies to be useful rather than being buried or cremated. For Bolt, donors "choose to be different, to make a nonconformist decision". In this way body donors were described as "independent, strong and selfdetermined" (Bolt, 2010).

In India (Rokade and Gaikawad, 2012) the main reasons not to donate were related to the interest in performing religious rituals and fear about misuse of bodies. Consistent with our study, in Pennsylvania a high percentage of respondants reported they had insuficient information (Larner et al., 2015), despite which, $54 \%$ had interest in donating $(p=0.0246)$ but only 5 were just registered. These authors considered that lack in education about whole body donation and registration process may be the cause of shortage of cadaveric donors.

It is clear that there are important differences between countries, not only due to ethnic (in some countries), cultural and religious aspects but also associated to the popular information and facilities to register as donors; then, no recipe could be applied for a body donation program but it has to be addapted to the local profile. 
The study is conclusive in showing that women, young and old, with high educational level and preferently non-professing any religion are the best candidates to donate their own bodies. However, increasing information could modify this profile as it was one of the main requests during the survey. Procurement should consider that altruism and solidarity are the main feelings supporting this attitude.

\section{Conflict of interest \\ None}

\section{Funding}

This study was supported by the Incentive Program 2018-19 of the SECYT-UNC 33820180100313 CB01.

\section{Ethical Approval \\ Not necessary}

\section{Informed Consent}

Survey participants were informed about the scope of the project and, in every case, answering it was strictly voluntary.

\section{Contributions}

SNB: Conceptualization, data curation, formal analysis, funding acquisition, methodology, resources, project administration, supervision, writing. LMN: Investigation, methodology and resources. SGS: Investigation, methodology and resources. FT: Investigation, methodology and resources NL: Investigation, methodology and resources. AJBV: Investigation, methodology and resources. MAS: Methodology, resources, supervision, investigation. OPD: Conceptualization, funding acquisition, investigation, project administration, methodology, validation. DU: Data curation, methodology, resources, investigation. DMW: Investigation and resources. FNDO: Preparation and reception of the surveys. IEMV: Preparation and reception of the surveys.

\section{ACKNOWLEDGMENT}

Authors manifest their sincerely gratitude to all individuals who voluntarily donate their whole bodies for universitary teaching and research, and to their families to support them. We also thank to those who kindly participated answering the survey.

\section{REFERENCES}

Anyanwu EG, Obikili EN. 2012. Dissecting the Dissectors: Knowledge, Attitude, and Practice of Body Bequests by Nigerian Anatomists. Anatomical Science Education 5: 347-53.

Anyanwu EG, Obikili EN, Agu AU. 2014. The dissection room experience: a factor in the choice of organ and whole body donation-A Nigerian survey. Anatomical Science Education 7: 56-63.

Arraez-Aybar LA, Sanchez-Montesinos I, Mirapeix RM, Mompeo-Corredera B, SanudoTejero JR, 2010. Relevance of human anatomy in daily clinical practice. Ann. Anat. 192: 34148.

Arraez-Aybar LA, Bueno-López JL, Moxham B. 2014. Anatomists' views on human body dissection and donation: An international survey. Annals of Anatomy 196: 376-86.

Asad AL, Anteby M, Garip F. 2014. Who donates their bodies to science? The combined role of gender and migration status among California whole-body donors. Social Science \& Medicine 106: 53-58.

Asl JA, Nikzad $H$, Taherian A, Atlasi MA, Naderian H, Mousavi G,Kashani MM, Omidi A. 2016. Cultural Acceptability and Personal Willingness of Iranian Students Toward Cadaveric Donation. Anat Sci Educ 10: 120-26.

Azer SA, Eizenberg N. 2007. Do we need dissection in an integrated problem-based learning medical course? Perceptions of firstand second-year students. Surg Radiol Anat 29: $173-80$

Biasutto SN, Cárdenas-Valenzuela J, Prat GD, Romero-Reverón R, Medina Ruíz BA, Tamayo $S$, Paredes Orué R, Toledo Neto JL, Altamirano $J$, Ballesteros Acuña LE, Elia Martino de Vargas EC, Olivera E, Grgicevic GF, Amer MAR, David $O P$, Garategui L. 2018b. Situación de las Universidades Argentinas y Latinoamericanas en relación al material cadavérico para la enseñanza de la anatomía. Rev Arg de Anat Clin 10: 52-76.

Biasutto SN, Caussa LI, Criado del Río LE. 2006. Teaching Anatomy: Cadavers vs Computers. Annals of Anatomy 188: 187-90

Biasutto SN, David OP, Spinelli MA, Urrutia D, Bertocchi Valle AJ, Weigandt DM, Molina Vargas IE, Vargas RAA, Navarro LM, Siemsen $S G$, Turri F, Longoni N, De Oro F, Prost SA. 2019c. Research on body donation willingness in Cordoba-Argentina: medical and dentist doctors' attitude. Rev Arg de Anat Clin 11: 10714.

Biasutto SN, Garay MB, Rives MV, Uanini $F$, Albrecht A, Ortiz LB, Gerbaldo MV. 2018a. La percepción de los estudiantes de primer año de 
Medicina en la sala de disección y su incidencia sobre la procuración de cuerpos. Rev Arg de Anat Clin 10: 44-51.

Biasutto SN, Molina Vargas IE, Weigandt DM, Mora MV, Vargas RAA, Bertocchi Valle AJ, Uanini MF, David OP, Urrutia D, Spinelli MA, Olivera MNJ, Gimenez M, Nefa Salera $M$, Decouvette A, Ferrero LJ. 2019a. Reactions of first year medical students in the dissection room, with prosected corpses, and the incidence on own body donation. Rev Arg de Anat Clin 11: 18-29

Biasutto SN, Navarro LM, Turri F, Longoni N, Bertocchi Valle AJ, Siemsen SG, De Oro $F$, Molina Vargas IE, David OP, Spinelli MA, Urrutia D. 2020. Diferencia entre médicos y odontólogos respecto a la donación del propio cuerpo para docencia e investigación en Córdoba - Argentina. Rev Arg de Anat Clin 12: 17-22.

Biasutto SN, Spinelli MA, Weigandt DM, Mora MV, Bertocchi Valle AJ, Vargas RAA, Molina Vargas IE, David OP, Urrutia D. 2019b. Attitude of medical students to body donation in the National University of Cordoba - Argentina. Rev Arg de Anat Clin 11: 70-83.

Bolt $S$, Venbrux E, Eisinga R, Kuks JBM, Veening JG, Gerrits PO. 2010. Motivation for body donation to science: More than altruistic act. Annals of Anatomy 192: 70-74.

Boulware LE, Ratner LE, Cooper LA, Laveist TA, Powe NR. 2004. Whole body donation for medical science: A population-based study. Clinical Anatomy 17: 570-77.

Cahill KC, Ettarh RR. 2008. Student attitudes to whole body donation are influenced by dissection. Anat Sci Ed 1: 212-16.

Ciliberti $R$, Gulino M, Gazzaniga V, Gallo $F$, Vellone VG, De Stefano F, Santi P, Baldelli I. 2018. A survey on the knowledge and attitudes of Italian medical students toward body donation: Ethical and scientific Considerations J. Clin. Med. 7: 168-76.

Cornwall J, Perry GF, Louw G, Stringer M. 2012. Who Donates Their Body to Science? An International, Multicenter, Prospective Study. Anat Sci Educ 5: 208-16.

Dereje G. 2014. Reaction of medical students to experiences in dissection room. Ethiopian $\mathrm{J}$ Health Sci 20: 337-42.

Emue BEB, Jacks TW, Danladi SA, Nwegbu MM, Abue $A D$, Onwih EE. 2012. Problems and prospects of acquistion of human cadaver for medical education in Nigeria. J Pak Med Assoc 62: 1134-36.

Gürses IA, Ertaş A, Gürtekin B, Coşkun O, Üzel M, Gayretli O, Demirci MS. 2019. Profile and motivations of registered whole-body donors in Turkey: Istanbul University experience. Anat Sci Educ 12: 370-85.

Habicht JL, Kiessling C, Winkelmann A. 2018. Bodies for Anatomy Education in Medical Schools: An Overview of the Sources of Cadavers Worldwide. Academic Medicine 93: 1293-1300.

Halou H, Chalkias A, Mystrioti D, lacovidou N, Vasileiou PVS, Xanthos T. 2013. Evaluation of the willingness for cadaveric donation in Greece: A population-based study. Anat Sci Educ 6: 48-55.

Jiang J, Zhang $M$, Meng $H$, Cui $X$, Yang $Y$, Yuan L, Su C, Wang J, Zhang L. 2020. Demographic and motivational factors affecting the wholebody donation programme in Nanjing, China: $A$ cross-sectional survey. BMJ Open, doi:10.1136/ bmjopen-2019-035539

Larner SP, Mcquone B, Schober JM, Loukas M, Terrell M. 2015. Perceptions of the living dead: An assessment of knowledge and opinions about whole body donation, its process, and willingness to become cadaveric donors in Pennsylvania. Clinical Anatomy 28: 442-48.

Narvaez-Hernandez E, Murillo-Rabago El. 2014. Herramientas de estudio utilizadas por los alumnos de ciencias de la salud en la materia de anatomía. Inv Ed Med 3: 204-08.

Quiroga-Garza A, Reyes-Hernandez CG, ZarateGarza PP, Esparza-Hernandez CN, Gutierrezde la $O \mathrm{~J}$, de la Fuente-Villarreal D, ElizondoOmana RE, Guzman-Lopez S. 2017. Willingness toward organ and body donation among anatomy professors and students in Mexico. Anat Sci Educ 10: 589-97.

Rokade SA, Gaikawad AP. 2012. Body donation in India: social awareness, willingness, and associated factors. Anat Sci Educ 5: 83-89.

Saha A, Sarkar A, Mandal S. 2015. Body donation after death: The mental setup of educated people. Journal of Clinical and Diagnostic Research 9: 5-9.

Sugand K, Abrahams P, Khurana A. 2010. The anatomy of anatomy: a review for its modernization. Anat Sci Educ 3: 83-93.

Techataweewan $N$, Panthongviriyakul C, Toomsan Y, Mothong W, Kanla P, Chaichun A, Amarttayakong P, Tayles N. 2018. : Human body donation in Thailand: Donors at Khon Kaen University. Ann Anat 216: 142-151.

Volanek AF, Rissi R. 2019. Perspectiva da doação voluntária de corpos para utilização no ensino de anatomia: consciência social, disposição e fatores asociados. Rev. Ciênc. Méd. 28: 77-84 